\title{
VESTIGIOS ORIGINALES DE LA DÍKE: EN LOS ORÍGENES DE LA FILOSOFÍA DEL DERECHO EN LA ÉPOCA ARCAICA HELÉNICA
}

\author{
HÉCTOR GARCÍA CATALDO \\ Pontificia Universidad Católica de Valparaíso. Chile
}

Resumen: En este artículo, tal como se anuncia desde su título, me propongo tratar acerca de los vestigios de la idea de la $\delta$ íkך en los testimonios originales que nos quedan de la época arcaica del mundo y del pensamiento heleno y cómo estos orígenes, de una u otra forma, determinan lo que más técnicamente podríamos llamar una filosofía del derecho en el marco de una reflexión posterior acerca de la filosofía política, cuyo horizonte también hay que situarlo en el propio mundo heleno.

Palabras clave: dike, filosofía del derecho, época arcaica, filosofía política, Hélade.

\section{ORIGINAL REMAINS OF DIKE: IN THE ORIGINS OF PHILOSOPHY OF RIGHT IN HELLENIC ARCHAIC EPOCH}

\begin{abstract}
In this article, as its title announces, I intend to deal with the remains of the idea of $\delta$ í $\eta$ in the original testimonies which we have from the archaic epoch of the world and of Hellenic thought, and how these origins, in one way or another, determine what more technically we could call a philosophy of right within the frame of a later reflection on political philosophy, whose horizon must also be located in the same Hellenic world.
\end{abstract}

Key words: dike, philosophy of right, archaic epoch, political philosophy, Hellas.

Recibido: 19.05 .15 - Aceptado: 30.06 .15

Correspondencia: Héctor García Cataldo.

Mail: hgarcia@ucv.cl-hgcataldo@hotmail.com

Licenciado en Filología Clásica con Opción Helénica y Latina.

Magister en Historia con Mención en Historia Europea y Doctor en Filosofía.

Profesor en Instituto de Filosofía de la Pontificia Universidad Católica de Valparaíso.

Tel. 032-2274391; Universidad de Chile, Tel. 02-2392292;

Universidad de Playa Ancha y Universidad de Talca, sede Santiago. 


\section{Reflexión preliminar ${ }^{1}$}

Tal como se enuncia en el título de esta presentación, se trata,

1 simplemente, de introducirnos en el mundo de la idea de dike en los testimonios originales que nos quedan de la época arcaica del mundo y del pensamiento heleno y cómo estos orígenes, de una u otra forma, determinan lo que más técnicamente podríamos llamar una filosofía del derecho en el marco de una reflexión posterior acerca de la filosofía política, cuyo horizonte también hay que situarlo en el propio mundo heleno.

Un segundo aspecto que tenemos que considerar es que estos vestigios refieren a un determinado período de la historia, esto es, la época arcaica y especialmente acotada a su primera etapa, considerando los aspectos indispensables para su comprensión en su devenir hasta el siglo sexto en estricto rigor.

Es imposible no tener presente la primera mitad de la referencia de este

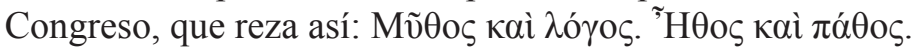

Ha sido una tradición del pensamiento contemporáneo plantearse el problema del tránsito del mito al lógos, generándose, así, una disociación entre ambos, máxime cuando se lleva esta disociación al extremo y se dejan ver como opuestos (mito y razón, donde tránsito sería el proceso mental que dio lugar a la filosofía como conocimiento racional riguroso). Del éthos y páthos, del primero tenemos el sentido originario de nuestra concepción de la ética, fundada a partir de su é $\theta o \varsigma$, como diría el estagirita. El páthos señala el modo, la manera cómo nos las habemos con el mundo, la realidad: esa realidad es pathetiká, en el sentido de que el páthos es lo que nos permite sentirnos afectados de cualquier sensación (pasión), sentimiento, es un dejarse impresionar por todo lo que afecta nuestros sentidos y que son los determinantes, a su vez, en la conformación de lo que podríamos llamar nuestro $\tilde{\eta} \theta o \varsigma$, tando individual como social. Veo en la

1 Este trabajo, originalmente, fue presentado en el IV Congreso Internacional de

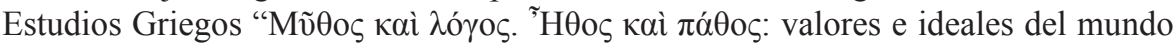
griego". Santiago de Chile 1, 2 y 3 de octubre de 2014, organizado por el Centro de Estudios Griegos Bizantinos y Neohelénicos "Fotios Malleros" de la Universidad de Chile y el Centro de Estudios Clásicos de la Universidad Mtropolitana de Ciencias de la Educación. Se presenta, aquí, con ligeras amplificaciones y las modificaciones de rigor. 


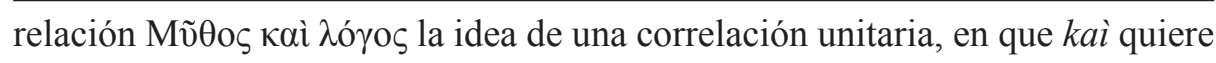
decir, un es decir, el mythos como lógos, el mito es manifiesto sólo por y a través del lógos, que criba cada pasión. Mito y logo devienen juntamente.

El mito es el imaginario que se expresa a través de la razón como palabra, un dar cuenta y razón, independiente de los medios a través de los cuales se presente. El mundo heleno en su etapa originaria se manifestó a través de su poetas, que nos permiten acceder a aquel imaginario de la díke, la que llegará a tener la preponderancia de ser vista como la areté en la que se concentran todas las virtudes.

\section{En los orígenes de una filosofía del derecho}

Aquí no se trata de hacer una historia de la filosofía del derecho y del Estado como sucesión de conceptos fundamentales acerca del derecho y de la pólis y sus problemas, ni tampoco se tratará de un rastreo a las problemáticas que una ciencia jurídica podría investigar en los vestigios literarios de la época arcaica para descubrir las diversas manifestaciones que ha experimentado el hombre heleno arcaico en la conquista de soluciones jurídicas. Hay abundantes investigaciones por parte de diferentes ciencias en estas materias. Nuestro interés es más básico: se trata de ver que a la interpretación, ya dada por Aristóteles, que los comienzos de la filosofía helena estarían dados por tomar como objeto de meditación el universo, el kósmos, se trata de ver, asimismo, también la idea de que en la antigua Hélade la reflexión acerca del mundo humano habría precedido a la reflexión en torno al mundo natural. Incluso más, a juzgar por los testimonios literarrios que nos han llegado, esta reflexión de mundo humano y mundo natural fueron una unidad muy estrechamente vinculadas. Allí donde haya una mirada en torno del hombre hay, al mismo tiempo, una profunda reflexión acerca de la naturaleza en su conjunto, lo que permitió una expresión poética a través del pensamiento analógico para profundizar en la imagen del hombre mismo. De esto da cuenta ampliamente toda la poesía homérica; bastaría examinar con cierta detención el sistema de las comparaciones en Homero, particularmente, en Ilíada. incluyendo lo que denominamos teogonías míticas, que más allá del politeísmo antropomórfico, conciben los problemas del Kósmos a partir de problemas humanos. Cuando el progreso del espíritu filosófico fue desantropomorfizando el mito, acentuando la explicación racional de la realidad, ese espíritu se convirtió en pensamiento fisico y que Aristóteles identificó como el pensamiento de los physikoí o naturalistas. Pero como 
también se ha señalado y demostrado, la filosofía naturalista para explicar el mundo natural se sirvió en su devenir de las categorías de la experiencia de la vida humana, que intuitivamente habían sido expresadas por el imaginario mítico, una de estas categorías fundamentales es la noción de vó $\mu$ o en tanto que "ley", cuyo origen y desarrollo es propio del ámbito social. De modo que ese proceso de tránsito, de mito a lógos, no se realizó de golpe y de una vez, sino que fue un proceso gradual en que ambos, mythos y lógos coexistieron como pocedimiento para enfrentarse al misterio del ser. No por nada el estagirita señaló que el filósofo en cierta medida es un amante de los mitos ${ }^{2}$, esto es, no puede haber separación tan radical entre mito y lógos o, dicho de otro modo, no puede haber separación tan radical entre pensamiento mítico y reflexión filosófica, pues el $\theta \alpha \tilde{v} \mu \alpha$ es signo de su articulación, cuestión que Aristóteles captó profundamente y que puso en evidencia a largo de toda su filosofía.

En el mundo arcaico heleno, la reflexión llegó a la convicción que existe una conexión fundamental entre la esfera de las relaciones sociales humanas y la

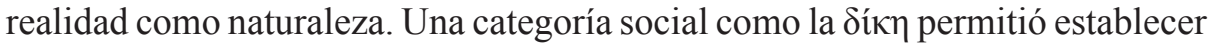
dicha cenexión esencial y que luego continuó su propio periplo, orientando el desarrollo de la humana civilización, que, pese a las cruentas luchas sociales de los siglos VII y VI a. de C., terminó por formar parte de un ethos colectivo fundamental y siendo gozne articulatorio no sólo de una filosofía política como en el período del surgimiento de los grandes sitemas, sino también de una filosofía del derecho al alero de aquella misma teoría política. En este sentido es acertada la observación de W. Jaeger cuando señala que los helenos se entregaron intensamente a la especulación acerca de la naturaleza del derecho y la justicia mucho antes que crearan una filosofía jurídica, según el uso actual que le damos al concepto ${ }^{3}$. Asimismo, mucho antes que crearan una teoría ética, los helenos se encontraron de lleno con la experiencia de una conducta en el acontecer humano y como ha señalado Léon Robin los intérpretes de la reflexión moral son los poetas y luego los legisladores, porque las demandas a las que ellos responden son las exigencias que demanda la vida en común ${ }^{4}$. Es

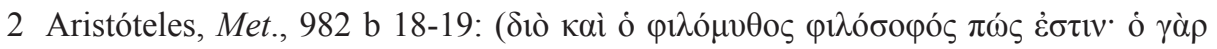

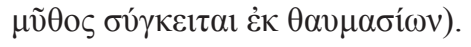

3 Cfr., Alabanza de la ley: los orígenes de la filosofía del derecho y los griegos. Traducción de A. Truyol y Serra. Centro de Estudios Constitucionales. Madrid, 1982, págs. 3-4.

4 Cfr., Robin, Léon, El Pensamiento Griego: y los orígenes del espíritu científico. 
el propio Robin, quien a principios del siglo pasado (1923) echaba de menos que la reflexión moral de los helenos de la época arcaica, expresada por sus poetas y legisladores del período de las codificaciones, se convirtiera en materia de estudio filosófico, para él las expresiones literarias eran la expresión del esfuerzo del pensamiento griego para "coordinar y formular en concepciones de una importancia general los datos de la conciencia colectiva, relativos a la vida y a la conducta humana" ${ }^{5}$, dicho de otro modo, se trata del esfuerzo de llevar a principios universales los datos de la conciencia colectiva, que han surgido de la vida y la conducta humana; tal es lo que guardan los poemas de Homero y Hesíodo y por esas mismas razones se habrían convertido en obras educadoras de la juventud helena y, luego, "servirán de base a toda discusión sobre los problemas morales". La obra de Hesíodo, los Erga, representaría para Robin un "notable progreso en la determinación de las ideas morales", pero pese a que no podamos buscar en esta obra una doctrina filosófica, en sí mismo la obra de Hesíodo "no deja de ser una reflexión virtualmente racional sobre el contenido y las aspiraciones de la civilización griega, en una sociedad y en una época determinadas"8. Es esta virtualidad racional de la reflexión poética arcaica la que no debemos perder de vista cuando pensamos en la expresión tránsito del mito al logos.

La reflexión que entraña los vestigios de una ética en la época arcaica la hallamos en todos sus poetas, partiendo desde el mismo Homero y Hesíodo como en los naturalistas del mundo jónico y en el período clásico con mayor razón en los poetas trágicos, siendo común en todos ellos, como ha escrito Jaeger, "el ver la justicia como fundamento de toda vida humana digna y esto es de la mayor importancia, pues aquellos hombres veían al derecho y a la ley en su conexión orgánica con la totalidad de la humana civilización". . Si en algo vieron el fundamento de una posición distinguida que el hombre podía

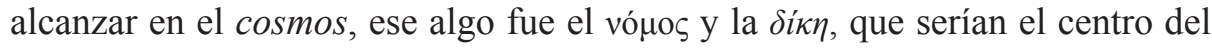
progreso y devenir de la cultura humana y determinarían el lugar del hombre mismo en el universo.

Traducción de Joaquín Xiráu P. Editorial Cervantes. Barcelona, MCMXXVI, pág. 26.

5 Ibidem.

6 Ibidem.

7 Id., pág. 27.

8 Ibidem.

9 Cfr., Jaeger, W., Op. Cit., pág 5. 
En los poemas homéricos encontramos unas primeras y abundantes referencias a la administración de la justicia, la que radica en los reyes; sin embargo, con respecto a una codificación de la ley como nomos no existe aún. Se trataba de un derecho consuetudinario, es decir, cuya práctica descansaba totalmente en la autoridad de la costumbre y la tradición oral. Los monarcas recibían su cetro y con él la autoridad de la ley, que venía del mundo celeste, de Zeus, quien era la fuente divina de toda justicia terrenal: así lo entiende Homero. Es la idea o concepción aristocrática de la justicia, que perdurará por siglos, con un carácter marcadamente jerárquico, acorde con una concepción de la areté heroica y de la supremacía aristocrática de la cultura de la época. Tradición que comienza su reestructuración hasta su modificación a partir de la severa crítica social de Hesíodo.

Si hay un ejemplo claro acerca de la justicia como centro de una vida en comunidad es el que hallamos en la Ilíada, la magnífica descripción del escudo de armas de Aquiles, cuyas decoraciones representan las características de todas las actividades humanas, desarrolladas en la época, diríamos que se describe en él la vida cotidiana de la polis, representa como un paréntesis esta descripción en el marco general de la dura contienda heroica. En contraste se representan dos ciudades: una en paz y, otra, en guerra. Nos interesa de momento la primera, pues en el centro de su descripción aparece la solemnidad de un pleito judicial. Se ven sentados sobre pulimentadas piedras, los ancianos, jueces que dirimirán en una causa de homicidio ${ }^{10}$. Aquí, no se describe un simple litigio, sino que se

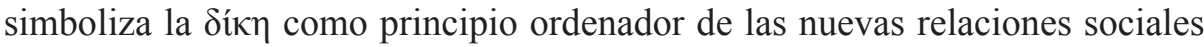
emergentes en el nacimiento de la pólis. Hay la apelación a un derecho como sustituto muy probablemente de la simple némesis, esto es, de la simple justicia divina vengadora. Este pasaje de la Ilíada ha dado origen a un sinnúmero de problemas e interpretaciones, que no es posible tratar aquí ${ }^{11}$. Pero, sin duda, hay aquí el esbozo más antiguo de un procedimiento aplicado por el derecho y que ha sentado, en cierto modo, el principio de la argumentación entre las partes en conflicto; el texto se cierra con la idea que se darían las monedas de oro al que de entre ellos, los litigantes, dijera muy rectísimamente la dike $\tau \tilde{\varphi}$

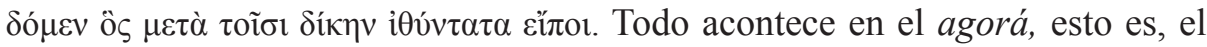
poeta ha remarcado el sentido público del proceso, bajo una estructura circular

10 Véase Il., XVIII, 497 sigs.

11 Al respecto puede verse el magnífico estudio de Sergio Fusai, Il processo omerico:Dall' histor omerico all' historíe erodotea. CEDAM, Padova, 2006. 
de carácter sagrado y los ancianos portando el cetro en sus manos, símbolo de un proceso ordenado en el ejercicio de la palabra al emitir su veredicto (su consejo) por turno, respectivamente. Este imaginario (mythos) homérico acerca del agorá, será, posteriormente, la clave de todo el desarrollo político del mundo heleno.

Otras referencias podemos revisar en la Odisea, por ejemplo, cuando Odiseo desembarca en un país desconocido, se pregunta con cierta ansiedad: "¿Qué hombres deben de habitar esta tierra a que he llegado?

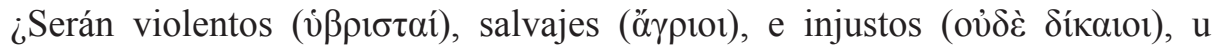

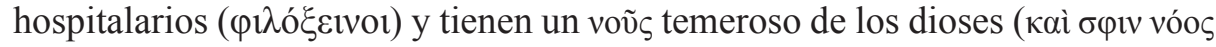

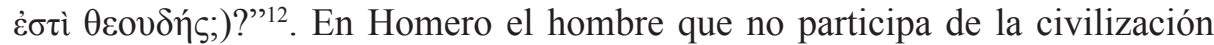
conserva el estado primitivo en que impera la hybris y un estado de salvajismo

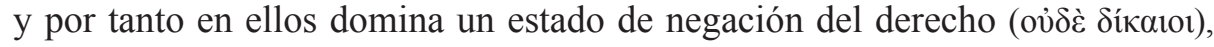
y si no de negación, sería preferible decir, que en ellos no existe la idea de derecho, esto es, de justicia. De las mismas palabras de Odiseo se desprende que un concepto clave de la justicia en el mundo homérico está dado por el compromiso que conlleva la palabra empeñada: hay injusticia e insensatez cuando a un hombre se le promete (dice) que llegará a una determinada parte o encontrará tal o cual cosa y ello no ocurre. Este mismo sentido es el que aún estará presente en Arquíloco de Paros, en el famoso texto contra su suegro Licambes ${ }^{13}$.

Para Homero dike era la línea de demarcación entre la barbarie y la civilización, para Arquíloco el límite entre la amistad como compromiso, juramentado y la traición. Allí donde haya justicia el hombre pisará sobre suelo firme, siendo, incluso, un peregrino en tierra extranjera. El mundo bárbaro de los Polifemos, de los Cíclopes que aún viven el primitivismo, es un mundo sin $\theta \varepsilon ́ \mu \iota \varsigma$, es decir, sin derecho ${ }^{14}$, sin ley, pues carecen de lo más preciado que se

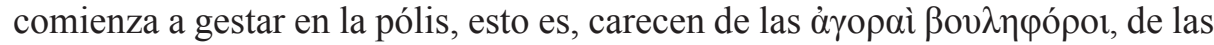
asambleas productoras de consejos, donde se toman los sabios acuerdos y las

12 Véase Od., VI; 119 sigs.; IX, 175 sigs.; XIII, 200 sigs.

13 Cf. Arquíloco, frag. 79a D, Edmonds 97a:

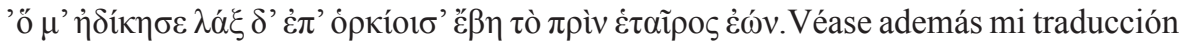
en Poesía Lírica Griega Arcaica del Siglo VII a. C. Antología de Fragmentos de Arquíloco a Anacreonte. Pags. 46-47. Universidad de Chile. Santiago, 1998.

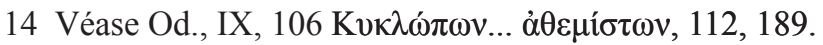


justas decisiones ${ }^{15}$, por tanto no conocen tampoco las normas de justicia (oü $\tau \varepsilon$ $\theta \varepsilon ́ \mu 1 \sigma \tau \varepsilon \zeta)$, donde el poderoso es señor y juez de su mujer e hijos ${ }^{16}$, pues no ha nacido en este tipo de hombres el imaginario de la ocupación del hacerse cargo de los problemas entre sí, su privatismo es su primitivismo.

Este mismo mundo homérico y su concepción aristocrática es, por oposición, el punto de partida de las "ideas innovadoras", según Francisco Rodríguez Adrados. Asistimos, por otra parte, a un naciente traspaso del mito al racionalismo, a los primeros y conscientes pasos hacia una idea de la pólis y a la purificación de la idea de lo divino. Todo esto bajo un mismo prisma, que es el de la idea de la justicia.

Hesíodo es quien encabeza, en el siglo VIII, este movimiento innovador, para quien la idea de la existencia de un orden general, basado en un principio divino despertaba una esperanza y vislumbraba un sentido diferente para la vida. En la Teogonía, en la que intenta una descripción lógica de la genealogía de los dioses, que cuatro siglos más tarde Aristóteles calificaría de pensamiento racional en forma mítica ${ }^{17}$, Hesíodo funda el orden natural del mundo en la justicia. Allí, cuenta el poeta, que en los matrimonios de Zeus con divinidades, luego de su primer casamiento con Metis, "la más sabia de los dioses y hombres mortales" ${ }^{18}$ el dios tomó como segunda esposa nada menos que a la "brillante" $\Theta \varepsilon ́ \mu ı \varsigma$ (Themis), nacida de Gea y Urano ${ }^{19}$ y hermana de

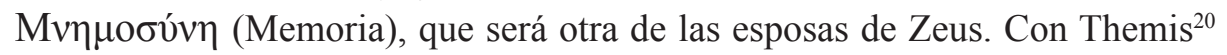
engendra a $\triangle$ ík $\left(\right.$ Justicia) ${ }^{21}$, a las Horas, a Eunomía, a Eirene y a las Moiras;

15 Respecto de este asunto acerca del juzgar y decidir, quien lo ha explicado con propiedad ha sido el filósofo Cornelius Castoriadis no sólo en su obra capital La institución imaginaria de la sociedad, sino muy especialmente en la Conferencia de 1982, cuyo original inglés fue publicado en 1983 "La polis grecque et la création de la démocratie", en Domaines de l'homme. Les carrefours du labyrinthe 2. Éditions du Seuil. Paris, 1986, pág. 333 ss.

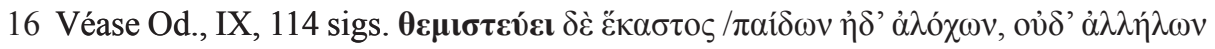

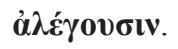

17 Cf. Metafisica. B 4, 1000 a 8; cf., 9.

18 Teogonía, vs. 886 y sigs.

19 Id. v. 135.

20 Id. v. 901 y sigs.

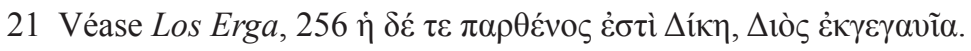


principios abstractos, pero operantes, que organizan las actividades del hombre por las cuales se alcanza la felicidad y/o la desgracia. Para Jaeger estas divinidades designarían "aspectos distintos de un orden social ajustado a leyes y son testimonio del interés creciente que en la época de Hesíodo se sentía por el problema de los fundamentos de la humana sociedad"22.

Sobre esta concepción de la Dike como diosa protegida de Zeus, es que se puede entender por qué el mundo griego del período arcaico y clásico puso tanto interés en esta abstracción que instaló como fundamento del desarrollo social del hombre, llegando a considerarla, los filósofos, entre las tres principales virtudes.

En la obra autobiográfica, los Erga, Hesíodo nos introduce, quizá por vez primera, en el ámbito de lo estrictamente personal, y nos muestra al hombre en el ejercicio elemental de su existencia cotidiana, los problemas más inmediatos y familiares, que nos dan una base acerca de las conductas personales que el hombre ya practica, a saber, el abuso (v̋ßpıs), que no es puramente entendido como simple transgresión divina; aquí se trata de transgresión en el terreno de lo propiamente humano, se trata del agravio, de una soberbia que se impone violentamente sobre el otro, reflejada claramente en la historia del gavilán y el ruiseñor, el abuso llevado al extremo. Ante esto el poeta esboza la imagen de lo opuesto, de la dike , la justicia, que es el imperativo categórico de la obra: la invocación al hermano Perses:

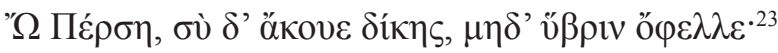

¿Qué es este ákoue díkes?, que algunos han pensado como "obedece a la justicia", que no es errónea traducción, pero le hace perder el sentido elemental a la obediencia y el sentido originario que la "justicia" representaba para el poeta y tal vez para muchos de su generación, a saber, el de que la justicia primero se "oye". La justicia se escucha en la conciencia como un substrato incondicionado en el que se apoya el obrar del hombre, porque la

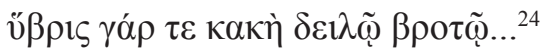

22 Alabanza de la Ley. Op. cit., pág. 10.

23 Los Erga, 213: “¡Oh Perses!, pero tú escucha a la justicia, no aumentes la hýbris”. 24 Id. v. 214. 
«porque la hybris es mala para el débil mortal...”. Es preferible el camino que nos pone en la pista de las cosas justas ${ }^{25}$, pues la justicia se eleva por sobre cualquier iniquidad. Esta es la fe, la esperanza hesiódica en una justicia trascendente que se cumple finalmente: “... la justicia está por sobre la hybris, desplegándose hasta el final, y habiéndola padecido (hasta) un tonto la conoce"26.

La dike se conoce en tanto que experiencia. Hesíodo ve también el progreso de la civilización en el respeto a la justicia y sobre todo a quienes la practican $^{27}$, porque la justicia está asociada con otro gran valor, a saber, el de

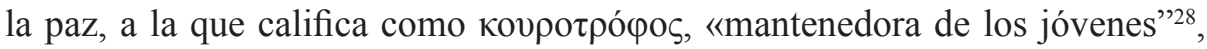
pues jamás Zeus les enviará "la terrible guerra" 29 y nada malo ocurrirá a estos

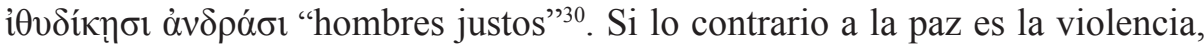
violencia que se expresa en la guerra, destructora de hombres, y por tanto destructora de un orden social, podemos pensar, entonces, que Hesíodo ha sido el primero en entrever esta relación causal entre carencia de justicia, del derecho, y violencia social, independientemente de lo señalado por W. Jaeger, para quien el primero en ver este problema objetivamente ha sido Solón y que de tal índole es el descubrimiento proclamado por el poeta y político ${ }^{31}$. Este sentido que atribuye a la justicia es el que se traduce en el ejercicio del hombre laborioso: ser justo es ser trabajador, por lo cual no se sentirán las penas del hambre y se disfrutará de los festines y de los frutos de la tierra, así como del nacimiento de la descendencia familiar futura. Para Hesíodo los justos "florecen entre cosas buenas ininterrumpidamente", ni tienen necesidad de abandonar sus propios campos sobre naves ${ }^{32}$. Para los que se interesan más en la nefasta hybris es la propia divinidad la que les prepara una dike que es juicio y condena. Un imperativo moral prima en la segunda parte de este mensaje a Perses:

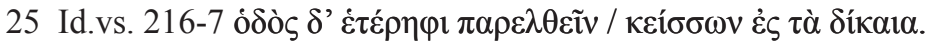

26 Id. vs. 217- 8.

27 Véase el pasaje vs. 219-237.

28 Id., v. 228.

29 Id., v. 229.

30 Id., v. 230.

31 W. Jaeger: Paideia: Los Ideales de la Cultura Griega. Fondo de Cultura Económica, pág. 142. México, 1957.

32 Los Erga, v. 236. 
Pero a los que llevan en la mente la injuria funesta y los crímenes, Zeus el Cronida, que mira lejos, les prepara la condena; y muchas veces toda una ciudad es castigada por culpa de un hombre malo que peca y trama acciones inicuas. A ellos el Cronida les envía desde el cielo grandes calamidades: hambre y peste juntas. Mueren los hombres, las mujeres no dan a luz, las casas se arruinan, conforme a la sabia voluntad de Zeus Olímpico ${ }^{33}$.

Esta dike tiene todas las características de ser una divinidad vengadora de actos inicuos, es como Ate, es juicio condenatorio, es también castigo de las culpas, y que Zeus la da a conocer a través de ciertas señales, señales destructoras, que recaen no sólo en el culpable directo, sino inclusive sobre toda la polis. Por esta fe y convicción positiva en la dike vengadora es que pide a los jueces, "varones devoradores de presentes" 34 , que examinen profundamente las características de esta justicia "porque los inmortales por estar cerca y entre los hombres observan a los que oprimen a los demás con juicios inicuos

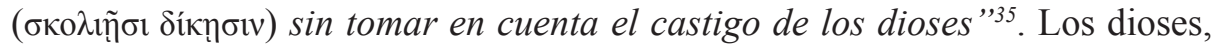
y Zeus en particular, representan la encarnación divina de la majestad de la justicia. La Dike agraviada acude a su padre al que le habla del nous de los hombres injustos y no precisamente para castigar al responsable directo, sino "para que el pueblo pague las injusticias de los reyes, quienes movidos por malos designios tergiversan la equidad y emiten sentencias arbitrarias" 36 .

Con esto, Hesíodo, ha establecido una relación "entre cualesquiera injusticia y el bienestar de la sociedad humana como tal" ${ }^{37}$. Nos queda absolutamente claro que para Hesíodo la justicia tiene su raíz y asiento en el ámbito divino, siempre vigilante, treinta mil guardianes inmortales son quienes vigilan los actos del hombre ${ }^{38}$, pero esta Dike está también referida al ámbito humano, que es a su vez la gran diferencia que separa al hombre de las fieras

33 Id., vs. 238 - 245 Traducción de Fotios Malleros K.

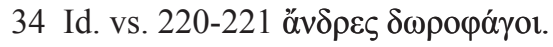

35 Id., vs. $249-251$.

36 Véase todo el pasaje 256-262.

37 W. Jaeger: Alabanza. Op. cit., pág. 12.

38 Los Erga, vs. 252-253. 
salvajes, y es el nous del hombre que debe reconocerla como un orden y ley natural por la cual éste logra el progreso, entendido simplemente como felicidad o prosperidad ${ }^{39}$, pero esta justicia divina ha sido traspasada a los hombres no como simple dádiva, sino como una imposición y como el bien supremo de la vida humana. Es así como el poeta cierra este círculo de la invocación a oír la justicia por parte de su hermano:

¡Oh Perses!, pero tú estas cosas ponlas entre tus sentimientos

y ahora escucha a la justicia y de la violencia olvídate totalmente.

Porque a los hombres esta ley impuso el Cronida:

a los peces, a los animales feroces y a las aves que vuelan devorarse unos a otros, puesto que justicia no hay entre ellos,

pero a los hombres dio la justicia, que es lejos la mejor ${ }^{40}$.

Mirada en su conjunto esta obra de Hesíodo, concordamos con Fränkel que estamos frente al trazado de «un cuadro de total corrupción moral» ${ }^{41}$ y que de aquí arrancaría la propuesta hesiódica de diferenciar las relaciones entre la ley y la violencia o como también ha entendido el profesor J. Millas que la tesis de dicha obra «se resuelve en la oposición de la vida social organizada por la justicia, a la vida natural fundada en la fuerza, es decir, del desorden animal al orden humano, de la violencia al derecho,... ${ }^{42}$, anunciando de esta manera el pensamiento filosófico posterior, haciendo de este poeta «el precursor de la filosofía de la cultura», tema que desarrollarán más tarde los sofistas, Sócrates, Platón y Aristóteles en quienes veremos los esfuerzos por conectar el tema de la justicia con los grandes temas de la filosofía política y muy especialmente con los fundamentos que permiten el afianzamiento de la pólis.

39 Id.Véase, 281.

40 Id., 274-280.

41 H. Fränkel: Poesía y Filosofía de la Grecia Arcaica. Pág. 120. Visor. Madrid, 1993. 42 Jorge Millas: Las Primeras Formas del Filosofar en la Poesía de Hesiodo de Beocia.

Anales de la Universidad de Chile. No 100, pág. 10. Cuarto trimestre, Santiago, 1955. 
El período en que vive el poeta es de grandes convulsiones sociales, y son éstas la causa de que se fuera perfilando cada vez con más fuerza la idea de la justicia como «expresión del orden moral que debe regir la convivencia social humana ${ }^{43}$ y tal es el sentido de la invocación a Zeus con la que se abre el poema, a quien se le pide que sea un restaurador del derecho conculcado ${ }^{44}$. Hesíodo dice que va a mitologizar, es decir, que hablará bajo la modalidad del mito, pero que este mito habla de cosas reales ( $\dot{\varepsilon} \tau \dot{\tau} \tau u \mu \alpha$ ), por tanto, su aspiración es una búsqueda de la verdad, y en este sentido su reflexión es virtualmente racional, donde mito y lógos apuntan en una misma dirección. Mirada desde esta perspectiva la tesis de O. Gigon que plantea retrotraer los orígenes de la filosofía helena a un estadio anterior al tradicional siglo VI, a la obra de Hesíodo, cobra plena vigencia ${ }^{45}$.

La obra de Hesíodo en la alborada de las ideas innovadoras sumistra los «slogans», nómos y díke, con los cuales se plantea la revolución social de los siglos VII y VI a. C., que transformarán el orden feudal del primitivo mundo griego, pero también su noción de la justicia traspasará las fronteras de la poesía, instalándose como una forma de interpretar el kósmos en la sofía de los jonios, aunque la reflexión de los naturalistas no haya estado dirigida directamente y sólo de modo incidental se ocupara de la vida social, no obstante las metáforas con las que se buscará la substancia, primordial, estable y unitaria del kósmos se tomarán de aquel primer imaginario homero-hesiódico. En los physikoí, Anaximandro de Mileto (610-547) trasladó la imagen de la dike al universo, hizo de la pólis humana una polis universal mayor, un kosmos sometido a una ley ordenadora. Más allá de los problemas interpretativos de su exiguo

\section{Id., pág. 10.}

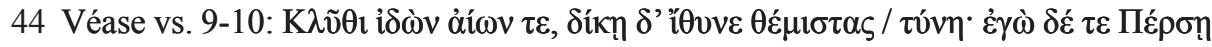

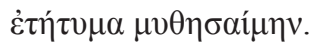

Tú, viendo y oyendo, toma conciencia y corrige con justicia las leyes divinas, y yo voy a hablarle en mythos cosas verdaderas a Perses.

45 Cfr., Gigon, O., Los Orígenes de la Filosofia Griega. De Hesíodo a Parménides. Editorial Gredos. Madrid, 1971, pág. 13 ss., donde plantea que al primero que podemos llamar filósofo es a un poeta, y que éste es Hesíodo, de quien se ha pasado por alto la audacia de su contenido, pues al volverse contra Homero ha tratado de "decir algo nuevo y distinto" y que "su obra sobre la historia de los dioses constituye el origen de la filosofía griega, en un sentido incomparablemente mucho más profundo que los escritos de Tales de Mileto colocados en el principio de la historia de la filosofía, desde Aristóteles y Teofrasto". 
fragmento parece afirmarse la existencia de una justicia cósmica inmanente que está en la base del nacimiento y disolución de los seres. Parménides, un poco después (ca. 475), piensa a la justicia, personificada en Themis y Díke justo ante la puerta donde se separan los caminos del día y de la noche, las vías de la verdad y la opinión. La justicia aparecerá en su poema como un principio que asegura la permanencia, la inmutabilidad del ser, nunca el ser devendrá del no-ser, ni que cosa alguna se disuelva, escapándose del ser, porque ahí estará díke, que no lo permitirá. Sabemos que las teorías pitagóricas también hicieron una trasposición del concepto de dike al de la justicia de los números y al de armonía, en el sentido de que la armonía propia de una sociedad es la que reinaría en el universo y de aquí el concepto de kósmos. Y sólo una vez que la sociedad de los siglos VII y VI a. C. llegó a la idea de que la tradición de las costumbres debía transformarse en nómos, en ley, y que esta ley debía estar formalmente escrita comenzó una etapa fundamental para el dinamismo

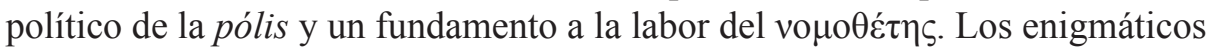
fragmentos de Heráclito, referidos al nómos y a la díke, sin duda habría que ponerlos en esa relación: 1) "También es ley obedecer la decisión de uno sólo" (33 DK), 2) "Debe el pueblo combatir por la ley como por la muralla" (44 DK), 3) "Los que hablan con inteligencia es preciso que se fortifiquen en lo que es común a todos, como la ciudad en la ley. Pues todas las leyes humanas se nutren de la única divina, ya que ésta domina cuanto quiere y a todas las auxilia y abarca" (114 DK) 4) "Conviene saber que el combate es universal, que la

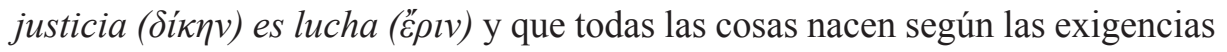
de la lucha y la necesidad" (80 DK).

Hacia fines de la época arcaica, el concepto de justicia había desembocado en un tal dinamismo político y de importancia que, tanto Focílides como Teognis dirán que:

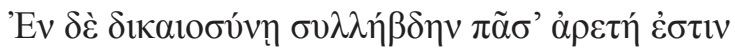

“En la justicia están reunidas todas las virtudes" (Teog. 147)

Y Teognis añade lo siguiente:

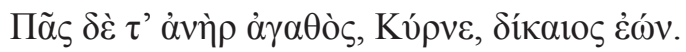
"y todo hombre bueno, Cirno, es justo" (Teog. 148). 
La ética de los tiempos posteriores se comprende mejor en el marco de su evolución, es decir, en el de toda la cultura precedente tal y como se fue manifestando a medida que la misma polis se hacía de la autárkeia, de la autodeterminación, apoyada por los vestigios de una filosofía del derecho, y una serie de eventos socio-políticos, culturales y económicos, cuyas consecuencias se manifestarán en todas sus diferencias en el siglo siguiente y que se expresarán mediante el surgimiento de nuevos géneros narrativos. 


\section{REFERENCIAS BIBLIOGRÁFICAS}

\section{FUENTES, EDICIONES, TRADUCCIONES}

ARISTÓTELES, (1970), Metafisica. Edición trilingüe por Valentín García Yebra. Madrid: Editorial Gredos.

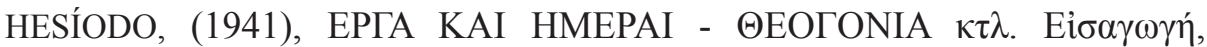

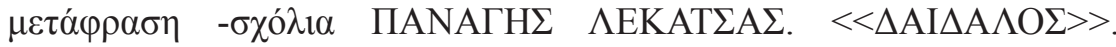
'A $\theta$ íva: Kaktos.

- $\quad$ (1962), Los trabajos y los días. Edición bilingüe. Introducción, traducción y notas de FOTIOS MALLEROS K. Santiago: Editorial Universitaria.

HOMERO, (1839), Homeri Odyssea. Tomus I, II. Lipsiae: Sumptibus et Typis Caroli Tauchnitii.

\section{COMPLEMENTARIA}

CASTORIADIS, C., (1986), Domaines de l'homme. Les carrefours du labyrinthe 2. Paris: Éditions du Seuil.

FRÄNKEL, H., (1993), Poesía y Filosofía de la Grecia Arcaica. Una historia de la épica, la lírica y la prosa griegas hasta la mitad del siglo quinto. Madrid: Visor.

FUSAI, S., (2006), Il processo omerico: Dall' histor omerico all' historíe erodotea. Padova: CEDAM.

GARCÍA, H., (1998), Poesía lírica griega arcaica del siglo VII a. C. Antología de fragmentos de Arquiloco a Anacreonte. Santiago: LOM Ediciones.

Gigon, O., (1971), Los Orígenes de la Filosofía Griega. De Hesíodo a Parménides. Madrid: Editorial Gredos.

JAEGER, W., (1982), Alabanza de la ley: los orígenes de la filosofía del derecho y los griegos. Traducción de A. Truyol y Serra. Madrid: Centro de Estudios Constitucionales.

- (1974), Paideia. Los ideales de la cultura griega. México: Fondo de Cultura Económica.

MILLAS, J., (1955), "Las Primeras Formas del Filosofar en la Poesía de Hesíodo de Beocia". Anales de la Universidad de Chile. № 100. Cuarto trimestre. Santiago.

ROBIN, L., (1926), El Pensamiento Griego: y los orígenes del espíritu cientifico. Traducción de Joaquín Xiráu P. Barcelona: Editorial Cervantes.

- $\quad$ (1963), La morale antique. Paris: Presses Universitaires de France.

RODRÍGUEZ A., F., (1957), La democracia ateniense. Madrid: Alianza Editorial. 